\title{
ENHANCEMENT OF INTERNALIZATION OF DIPHTHERIA TOXIN RECOMBINANT FRAGMENTS IN SENSITIVE CELLS MEDIATED BY TOXIN'S T-DOMAIN
}

\author{
K. YU. MANOILOV, A. J. LABYNTSEV, N. V. KOROTKEVYCH, D. V. KOLYBO \\ Palladin Institute of Biochemistry, National Academy of Sciences of Ukraine, Kyiv; \\ e-mail: manoilovmail@gmail.com
}

Subunit B of diphtheria toxin (DT) and its R-domain differ by the presence of T-domain. The aim of the present work was to analyze the interaction of these toxin fragments with mammalian cells in order to evaluate the T-domain's influence on endocytosis in resistant cells. Internalization of recombinant fluorescent subunit B and R-domain was characterized in toxin-resistant L929 cells derived from mouse connective tissue and toxin-sensitive Vero cells from African green monkey kidney. It was found that during incubation of cells in the presence of both subunit B and R-domain in the culture medium, Vero cells internalize more molecules of subunit B than of R-domain. Under the same conditions, $L 929$ cells internalize more molecules of R-domain than of subunit B. Colocalization of fluorescent subunit B and R-domain in L929 was rapid and proceeded almost completely at the early period of incubation compared to Vero cells in which it was slow and occurred gradually. The obtained data suggest that T-domain influence internalization and endosomal transport of DT in cells, which correlates with their toxin sensitivity. It was concluded that T-domain participates in intracellular endosomal transport and sorting of DT only in toxin-sensitive cells by enhancing the internalization of toxin molecules.

Key words: diphtheria toxin, endocytosis, internalization, proHB-EGF, confocal microscopy.

$\mathrm{D}$ iphtheria toxin (DT) is a single-chain protein of 535 amino acid residues produced by toxigenic strains of Corynebacterium diphtheriae, which were lysogenized by corynephage $\beta$ carrying the functional tox ${ }^{+}$gene [1]. DT is the main factor that causes the development of diphtheria symptoms. The cytotoxic action of DT is mediated by catalytic transfer of ADP-ribosyl group from $\mathrm{NAD}^{+}$to the diphthamide residue (modified histidine) in eukaryotic translation elongation factor 2 (eEF-2). This leads to an almost complete arrest of protein synthesis on ribosomes and cell death [1].

DT molecule is composed of two subunits: subunit A and subunit B (SubB). The A-subunit of DT consists of a single domain - the catalytic domain or C-domain (Cd). B-subunit is composed of two domains: receptor domain or R-domain (Rd), which is responsible for binding to the cell receptor, and transmembrane domain or T-domain (Td), which is involved in the process of Cd transfer in cy- tosol across the endosomal membrane. DT binding to its receptor on plasma membrane triggers internalization of DT-receptor complex through the clathrin-dependent endocytic pathway [2]. When $\mathrm{pH}$ in the endosomal lumen decreases during endosomal maturation, Cd enters in the cytosol where it modifies eEF-2. The exact molecular mechanism by which Cd passes through the lipid bilayer of endosome is unknown. However, it is supposed that $\mathrm{Td}$ plays the main role in this process as it can penetrate in the lipid bilayer [1].

DT receptor is the precursor of heparin-binding epidermal growth factor-like growth factor, proHBEGF. ProHB-EGF is a single-chain transmembrane glycoprotein of 146 amino acid residues [3]. There are two types of mammalian species in relation to their susceptibility to DT - toxin-sensitive and toxin-resistant. ProHB-EGF is present on cells of both types of mammals. SubB of DT binds via its Rd to the EGF-like domain of proHB-EGF, which is distin-

(C) 2017 Manoilov K. Yu. et al. This is an open-access article distributed under the terms of the Creative Commons Attribution License, which permits unrestricted use, distribution, and reproduction in any medium, provided the original author and source are credited. 
guished in sensitive and resistant species only by 10 amino acid residues [3].

Binding and internalization of recombinant DT derivatives (SubB, Rd, etc.) to cells from both of these organisms, as demonstrated in [4-6], suppose that the native toxin also enters both susceptible and resistant cells. It is believed that inside the resistant cells $\mathrm{Cd}$ is not transported to the cytosol from endosomal lumen [7], therefore these cells stay alive even in the presence of high doses of DT. However, there is no a confirmed assumption on how the mechanism of Cd transport prevention occurs in resistant cells. According to one point of view, due to the amino acid sequence differences in proHBEGF, DT detaches from this receptor under the low $\mathrm{pH}$ in resistant cells while in sensitive cells it retains its position near the membrane and therefore could penetrate into lipid bilayer.

Previously, we have created genetic constructs based on $p E T-24 a(+)$ vector $[8,9]$ for expression of the SubB fused to enhanced green fluorescent protein EGFP (EGFP-SubB) [9] and Rd fused with fluorescent protein mCherry (mCherry-Rd) [8]. It was also shown that EGFP-SubB is capable of binding and internalizing by mammalian cells both sensitive and resistant to the toxin $[4,9]$. It was found that recombinant DT products which contain the Td, produced by $E$. coli, retain their ability to conduct ions in artificial lipid bilayers $[10,11]$ and compensate the work of vesicular proton pumps in living cells [6]. Therefore, our recombinant derivatives of toxin retain the fully functional Td. Initial evidence of Td involvement in the regulation of intracellular transport of the DT was obtained in [5]. We suggested in [5] that coat protein complex I (COPI) can be involved in this process. The present work provides some new data on the intracellular DT transport.

The aim of the present study was to evaluate the Td's role in intracellular transport of DT in toxin-resistant cells and compare obtained results with sensitive cells. Recombinant DT derivatives are convenient tools for studying the endocytosis in cells dependent on proHB-EGF. EGFP-SubB and mCherry-Rd were chosen as model DT derivatives with and without $\mathrm{Td}$, respectively. The variation in numerous environmental parameters (temperature, medium composition, etc.) was leveled by simultaneous addition of both these proteins to the same incubation medium with mammalian cells. This allowed comparing the concurrent internalization of these proteins in a single cell. Different fluorescent labels (excitation and emission maximums for EGFP are at 489 and $509 \mathrm{~nm}$, respectively, while for mCherry at 587 and $610 \mathrm{~nm}$ ) allowed tracking by confocal microscopy B-subunit and Rd intracellular transport separately while cells were treated by EGFP-SubB/ mCherry-Rd mixture.

Murine L929 fibroblasts and green monkey epithelium Vero cells were chosen as the objects in the present work because they both are classical models of highly resistant and highly sensitive to DT species. Clone L929 derives from murine L cell line [12]. The major amount of studies on DT mammalian resistance were conducted on different subclones of L cell line [13-19]. On the contrary, Vero cell line was widely used as a standard of highly sensitive to DT cells [13, 14, 16-19].

As far as these cell lines are well-known and comprehensively studied examples of DT cytotoxic effects, they both stand at the forefront among the other cells for the study of mammalian DT resistance and are most suitable as the main objects for the present study.

\section{Materials and Methods}

In the present work there were used: bovine serum albumin (BSA), isopropyl $\beta$-D-1thiogalactopyranoside (IPTG) from Amersham (USA); acrylamide, N,N'-methylenebisacrylamide from AppliChem GmbH (Germany); 2-mercaptoethanol from Helicon (Russia); plastic Petri dishes from Greiner BioOne (Austria); kanamycin, glucose, chloramphenicol from "Kyivmedpreparat", Arterium Co. (Ukraine); 1,4-diazabicyclo[2,2,2]octane (DABCO), 7.5\% sodium bicarbonate solution, dibasic ethylenediaminetetraacetic acid sodium salt, foetal bovine serum (FBS), Hoechst 33342, LB medium, $\mathrm{NaN}_{3}$, paraformaldehyde (PFA), phenylarsine oxide (PAO), RPMI-1640 medium with L-glutamine, sodium dodecyl sulphate (SDS), stock solution of amphotericin B, penicillin $G$ and streptomycin for cell culture, Trisma base, Triton X-100, urea from Sigma (USA); imidazole from Shanghai Synnad (China); KCl, $\mathrm{NaCl}, \mathrm{Na}_{2} \mathrm{HPO}_{4}, \mathrm{NaOH}, \mathrm{KH}_{2} \mathrm{PO}_{4}$ from Miranda-C (Ukraine); nickel-nitrilotriacetic acid-agarose (Ni-NTA agarose), prestained protein markers for gel electrophoresis from Thermo Fisher Scientific (USA).

Mammalian cell culture. L929 and Vero cells were obtained from the collection of cell bank of Kavetsky Institute of Experimental Pathology, Oncology and Radiobiology, NAS of Ukraine, Kyiv. 
Cells were maintained on RPMI-1640 with $2 \mathrm{mM}$ of L-glutamine, $1.23 \mathrm{mg} / \mathrm{ml}$ sodium bicarbonate, $5 \% \mathrm{FBS}$ and antibiotics at $37^{\circ} \mathrm{C}$ under $5 \% \mathrm{CO}_{2}$ in the air [9]. Both cell lines were cultured under $5 \%$ concentration of FBS. Cells were used in experiments at $70-80 \%$ confluency.

Production of recombinant proteins by E. coli cells and their purification. Creation of the relevant genetic constructs based on pET24(+) vector with kanamycin resistance and protocols for protein expression in E. coli Rosetta BL21 (DE3) cells on LB media by IPTG induction can be found in previous publications $[5,9]$. Purification of proteins by $\mathrm{Ni}-$ NTA agarose column chromatography with imidazole elution gradient and determination of protein concentration by tricine SDS-PAGE analysis with TotalLab TL120 software were also performed according to $[5,9]$.

Flow cytometry. The protocol of sample preparation for flow cytometry, including cell detachment from Petri dish surface, assessment of cell density in a counting chamber, endocytosis suppression by $\mathrm{NaN}_{3}$ and low temperature $\left(4^{\circ} \mathrm{C}\right)$, adjusting conditions of incubation medium to reduce a cell surface non-specific protein adsorbtion by $1 \% \mathrm{BSA}$, is described in detail in $[4,5]$.

In control samples, both cell lines were incubated only in the presence of fluorescent proteins EGFP and mCherry, which were fused to neither parts of DT molecule. The concentrations of EGFP and mCherry in controls were equimolar to EGFPSubB and mCherry-Rd in experimental samples.

Determination of fluorescence intensity of the cells was performed using Coulter Epics XL (Beckman Coulter, USA) flow cytometer. The flow cytometer data was analyzed with FCS Express flow cytometry software.

Confocal microscopy. Sample preparation was according to $[4,5]$ : cells were grown on the glass coverslips, treated with target recombinant DT derivatives and Hoechst 33342 for nuclear staining; then followed PFA-fixation and mounting in polyvinyl alcohol media with DABCO as a non-specific fluorescence quencher and antifade constituent.

Cells were incubated in a simultaneous presence of both EGFP-SubB and mCherry-Rd in media during various time points of incubation (from 5 to $75 \mathrm{~min}$ ). EGFP and mCherry were used in the control to assess the general non-specific internalization of protein by cells.
Incubation in the presence of $20 \mathrm{mM}$ of PAO was carried out in separate samples in order to demonstrate the suppression of endocytosis in the cells [20].

Resulted samples were analyzed by Zeiss LSM 510 Meta (Carl Zeiss, Germany) confocal microscope.

Confocal image processing using ImageJ software [21] was carried out to analyze the endosomal internalization of fluorescently labeled proteins.

\section{Results and Discussion}

Determination of EGFP-SubB/mCherry-Rd working ratio by flow cytometry. Cell fluorescence intensity distribution in samples according to both EGFP and mCherry fluorescence was analyzed in Vero and L929 lines. Light scatter dot plots (FS versus SS) showed the homogeneity of cells in samples (data is not shown).

A molar proportion of EGFP-SubB and mCherry-Rd at which both these proteins have the same binding activity regarding proHB-EGF on the cell membrane was determined according to [5], where the same method of binding activity analysis was used for evaluation of simultaneous SubB and Rd interaction with Vero cells.

Under 2:1 molar ratio the same amounts of EGFP-SubB as well as of mCherry-Rd bound to Vero cells, and for L929 cells this proportion appeared to be also completely suitable. This relation of protein concentrations was used in the following confocal microscopy experiments.

Data analysis of simultaneous internalization of EGFP-SubB and mCherry-Rd by Vero and L929 cells. Confocal images (Fig. 1 and 2) show that DTresistant cells can bind and internalize both EGFPSubB and mCherry-Rd. In the presence of $20 \mathrm{mM}$ $\mathrm{PAO}$, which inhibits the formation of endosomes [20], fluorescent proteins were almost completely absent inside of the cytoplasm and localized on the cell surface (data is not shown). This confirms that these proteins were internalized in endosomes.

The calculation of the following parameters was carried out by image processing software [21]: endosome number in cells, total area of endosomes on a cell cross-section and average endosomal size. Analysis of selected values allows comparing the amounts of fluorescent proteins in cells at any time point of incubation, if assume that the quantity of protein molecules internalized by living cell is pro- 

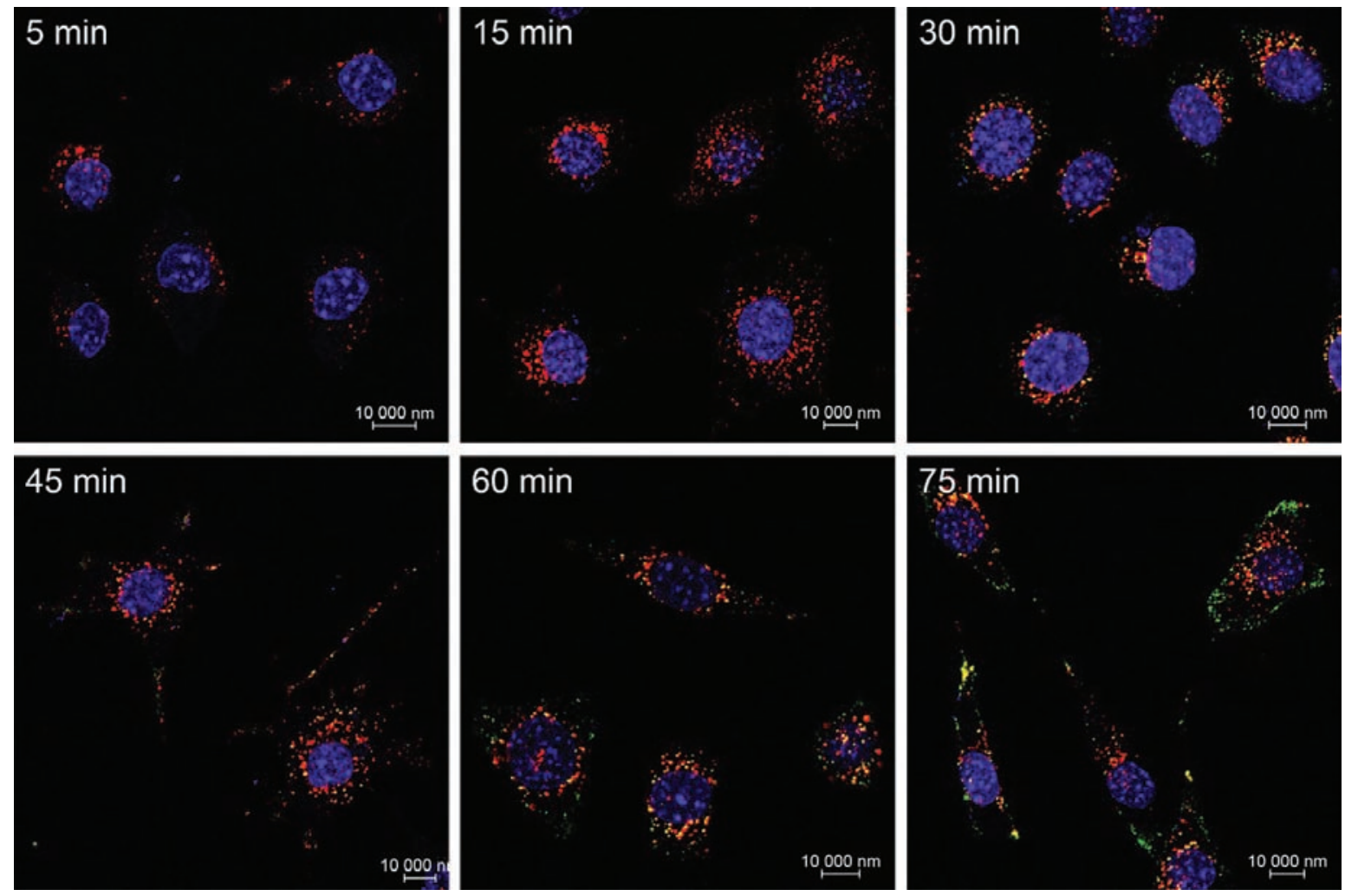

Fig. 1. Confocal images of L929 cells, incubated in the presence of both EGFP-SubB and mCherry-Rd proteins in a concentration when they bind in equivalent quantity to cells. EGFP-SubB is represented by green channel of fluorescence, $m$ Cherry-Rd - as red and Hoechst 33342 - as blue. Optical slice passes approximately through the middle of cells. According to typical experiment

portional to size and number of cellular vesicles (endosomes).

The presence of two different fluorescent labels (EGFP and mCherry) made it possible to track SubB and Rd separately in the same cell, while they were internalized simultaneously.

The internalization parameters mentioned above were calculated separately for EGFP-SubB and mCherry-Rd at various time points (Fig. 3). According to the obtained data in L929 cells the size of endosomes containing $\mathrm{Rd}$ is sufficiently bigger than that of endosomes containing SubB. Besides, the total area and number of endosomes with Rd are higher (or equal at 60-75 min; Fig. 3) than that of endosomes with EGFP-SubB. These data suggest that L929 cells internalize much more of Rd than of SubB.

Compared to L929 in Vero cells the average size of endosomes loaded with Rd is generally equal (at 5-60 min; Fig. 3) to the average size of SubB bearing endosomes. Moreover, at the later time points of incubation (60-75 min) the total area and endosome number are higher for the endosomes containing EGFP-SubB. These indicate that Vero cells internalize approximately the same amounts (or at the later time even more) of SubB as of Rd.

Thus, Td could affect internalization and endosomal transport of DT in cells according to their toxin sensitivity. Particularly, in toxin-sensitive cells Td could participate in intracellular endosomal transport and sorting of DT by enhancing the internalization and intracellular retention of toxin molecules while in toxin-resistant cells could not.

Colocalization of EGFP-SubB and mCherry$R d$ in Vero and L929 cells. The presence of two different fluorescent labels in studied recombinant proteins made it possible to not only characterize the endosome dynamics for these two molecules separately but also track the superposition (or colocalization) of both proteins in cells.

Colocalization rate was evaluated by Pearson's correlation coefficient (PCC) [22] and Mander's 

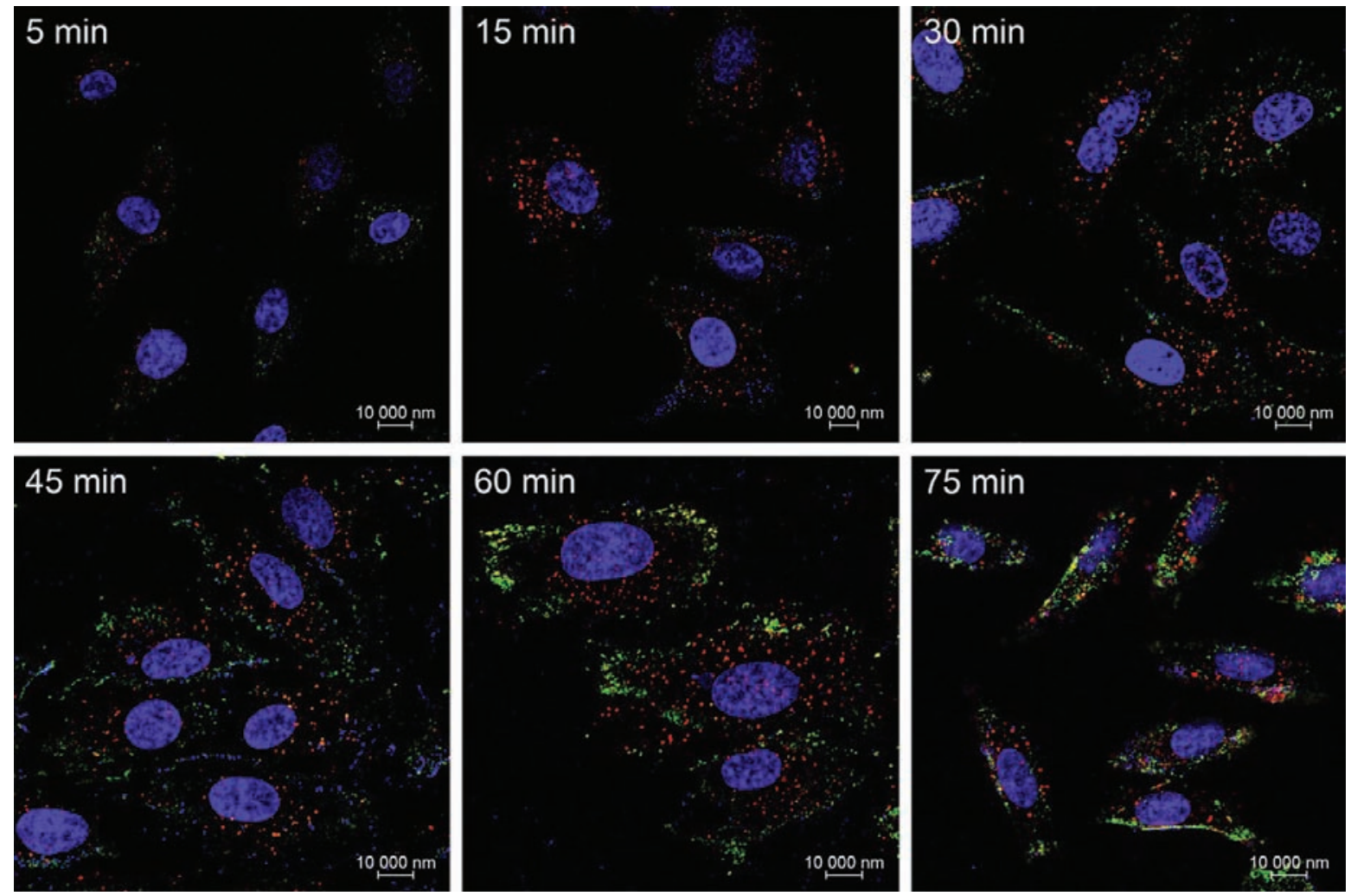

Fig. 2. Confocal images of Vero cells, incubated under the same conditions as L929 on Fig. 1. Representation and designations are the same as in Fig. 1. According to typical experiment

colocalization coefficients (MCC1 and MCC2). Calculation of both MCCs was carried out according to modification, described in [23].

PCC, M1 and M2 were calculated in each time interval of incubation from 5 to 75 min. PCC changed in L929 and Vero in the same way as MCC1 and 2 (data is not shown). At the early stages of incubation EGFP-SubB and mCherry-Rd were less colocalized in both cell lines than at later time periods. It was also found that time colocalization pattern is different in Vero and L929 cells (Fig. 4). L929 cells are characterized by rapid colocalization at the early stages of incubation (from 5th min), after which almost no changes in colocalization occurred. Compared to L929, Vero is characterized by a gradual increase in SubB and Rd colocalization rate throughout the whole incubation time.

Under the above-mentioned experimental conditions colocalization is most likely the measure of EGFP-SubB and mCherry-Rd commixture in the same endocytic compartments and is not an evidence of the protein-protein interaction between Bsubunit and Rd.
During endocytosis, EGFP-SubB and mCherry-Rd could be internalized in the same or different vesicles. Besides, different vesicles may occasionally fuse together during the process of intravesicular cargo sorting. Finally, both EGFP-SubB and mCherry-Rd move to endolysosomes where they could completely commix together.

Probably, dependence of colocalization on time reflects the differences in endosomal intracellular traffic of B-subunit and $\mathrm{Rd}$ in toxin-sensitive and toxin-resistant cells. Thus, commixture of both Td-containing and Td-free DT parts is different in studied toxin-sensitive and resistant cells. Moreover, rapid colocalization may indicate that the presence of Td does not influence the internalization and trafficking of studied toxin fragments in resistant cells.

There are some findings indicating that in DTsensitive cells toxin transport can be regulated by some factors alongside proHB-EGF. For instance, COPI, which is located at the outer side of the endosomal membrane, may facilitate the translocation of the C-domain of DT through the lipid bilayer by yet uncharacterized mechanism [5, 24]. 
A
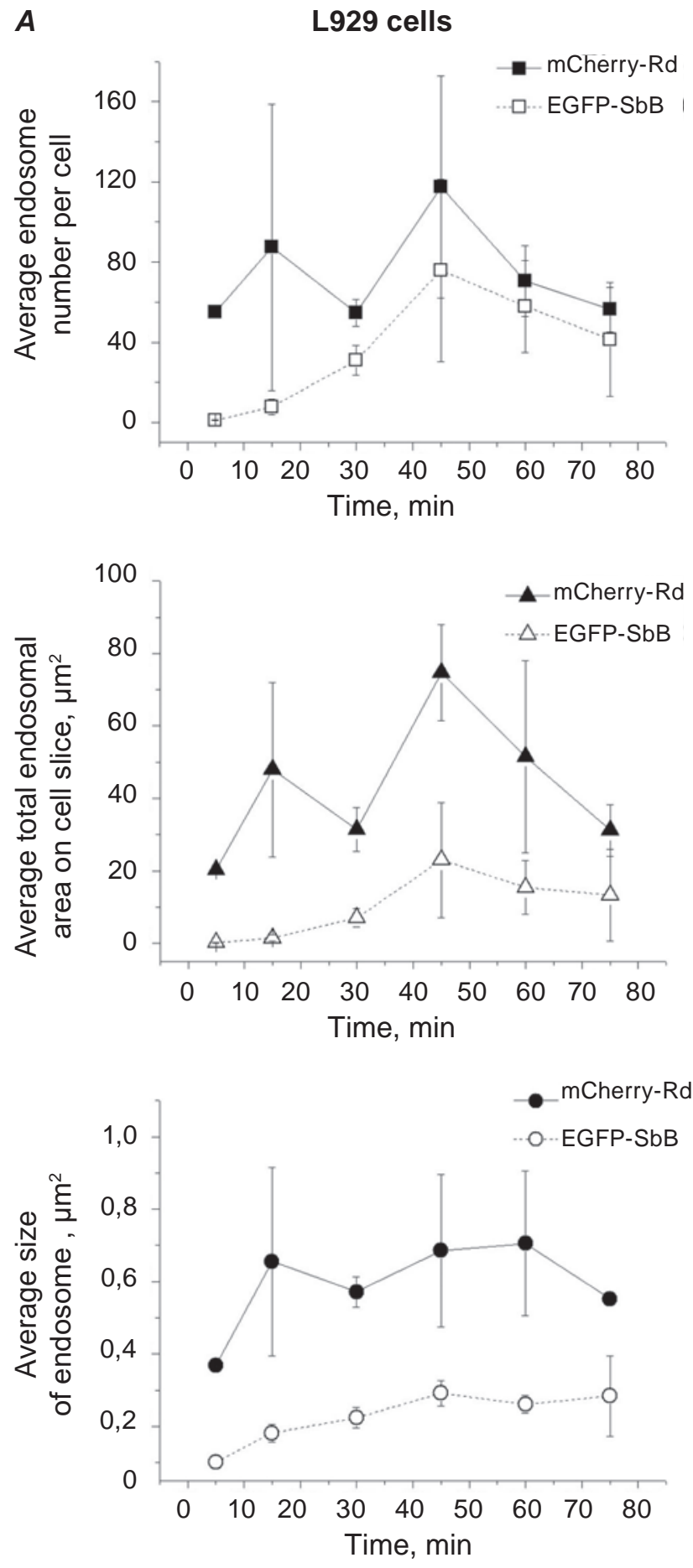

B
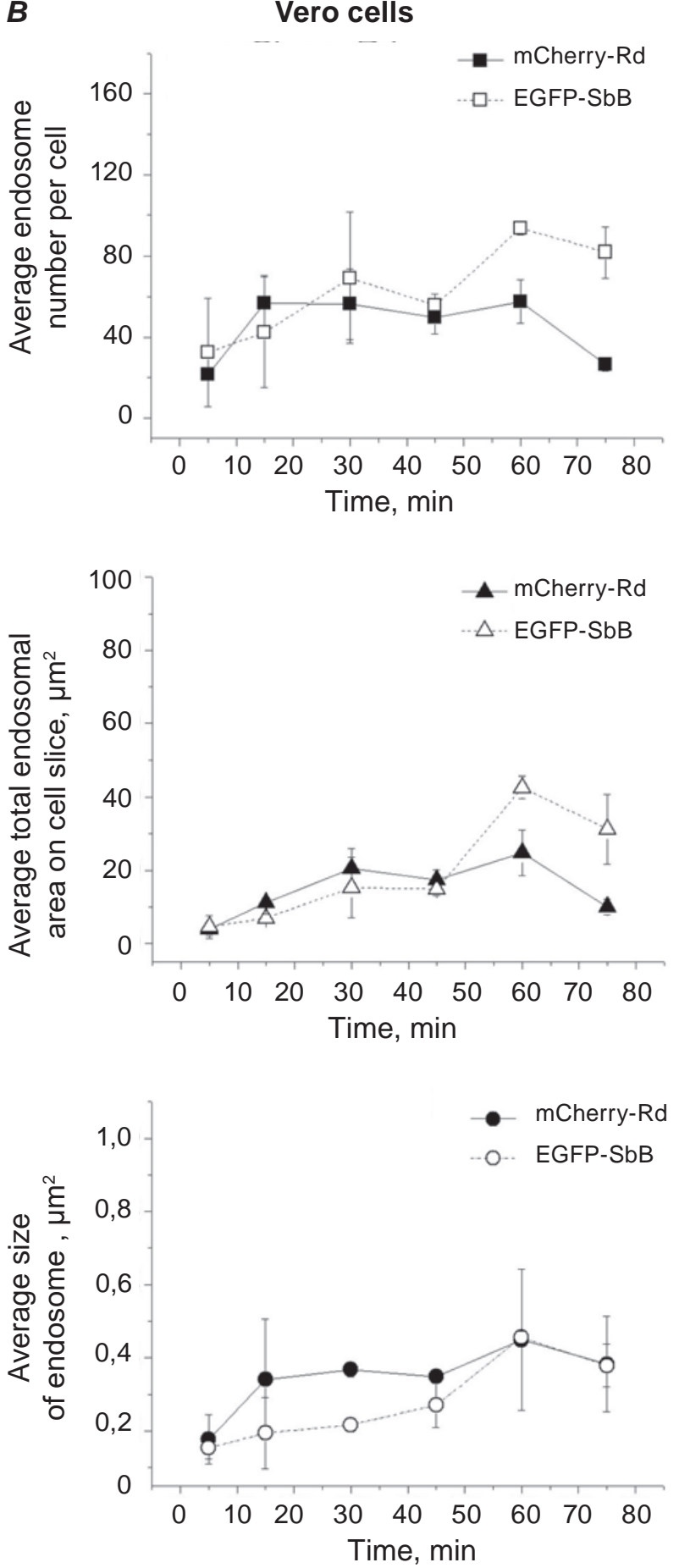

Fig. 3. Dependence of endosomal parameters on incubation time during simultanious internalization of EGFP-SubB and mCherry-Rd proteins by cells L929 (A) and Vero (B) cells $(M \pm S, n=3)$. The differences are significant relative to control samples $(P \leq 0.05)$

In mammalian cells, COPI may participate in sorting of early endosomes and retrograde vesicular transport in cells. We suppose that DT may affect these COPI-mediated processes probably via interacting COPI through the specific KXKXX motifs in the transmembrane helix 1 of the Td [25]. However, spatially COPI and DT are separated by the lipid bilayer of endosomal membrane. Therefore, if DT really affects the endosomal transport, some parts of toxin can also interact with COPI (and possibly 


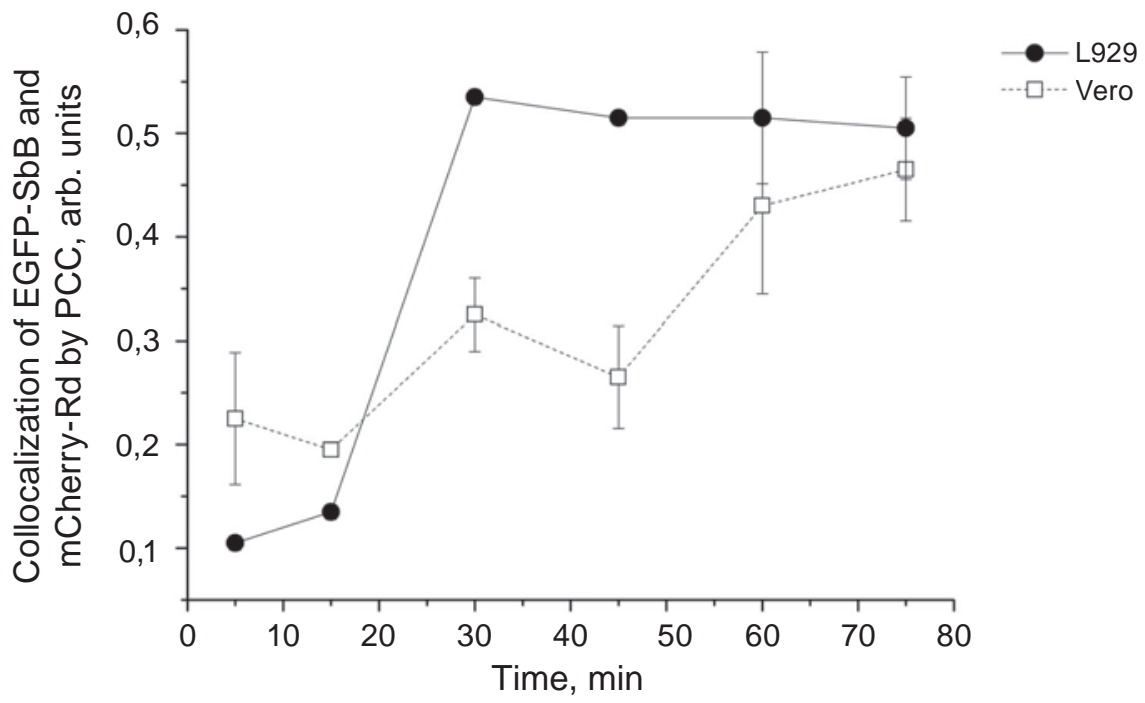

Fig. 4. Colocalization of EGFP-SubB and mCherry-Rd proteins versus incubation time by Pearson's correlation coefficient (PCC) in L929 and Vero cells $(M \pm S, n=3)$. The differences are significant relative to control samples $(P \leq 0.05)$

other molecules) as a result of partial penetration of Td through the endosomal membrane.

Based on the results on endosome trafficking and colocalization of SbB and Rd that were obtained in the present study, we suppose that in resistant cells DT does not participate in endosomal transport because its Td is not inserted in the bilayer and therefore - does not interact with COPI. Vice versa, in toxin-sensitive species toxin can participate in endosomal transport, because Td insertion is accompanied by interaction with COPI at the opposite site of the endosomal membrane.

If this is true, it could be also assumed that DT is unable to form ion conductive channels in endosomal membrane in resistant cells. This agrees with the data published in [6] and favor the hypothesis that toxin-resistant species are deficient in the $\mathrm{Cd}$ transport step [7], which is, hence, considered to be dependent on a channel formation by $\mathrm{Td}$.

In conclusion, we would like to notice once again our main findings. It is obvious that both SubB and Rd, produced in E. coli cells, are bound and internalized by toxin-resistant L929 cells as well as by toxin-sensitive Vero cells. However, we found that in selected cell lines internalization and intracellular endosomal transport of SubB and Rd are different.
It was shown that resistant L929 cells can internalize more molecules of Rd than SubB. Sensitive Vero cells can internalize equal amounts or slightly more molecules of SubB than Rd. Commixture of Rd and SubB occurs rapidly in L929 cells while gradually in Vero. This data can be explained by suggestion that COPI is responsible for SubB transport alterations in toxin-sensitive cells. It is not excluded that these differences may be connected with the implementation of the mechanisms of the resistance to DT.

Thus, our data suggest that Td affects internalization and endosomal transport of DT in cells according to their toxin sensitivity. We suppose that $\mathrm{Td}$ participates in intracellular endosomal transport and sorting of DT by enchancing the internalization of toxin molecules (probably through interaction with COPI) only in toxin-sensitive cells.

Acknowledgements. This work was supported by the grants of the National Academy of Sciences of Ukraine No 0114U003216 and No 0112U002624; and by the "Premium for young scientists" by the administration of Palladin Institute of Biochemistry of NAS of Ukraine for K. Yu. Manoilov in 2015. 
ПОСИЛЕННЯ ІНТЕРНАЛІЗАЦІї

РЕКОМБІНАНТНИХ ФРАГМЕНТІВ

ДИФТЕРІЙНОГО ТОКСИНУ

В ЧУТЛИВИХ КЛІТИНАХ, ОПОСЕРЕДКОВАНЕ Т-ДОМЕНОМ ТОКСИНУ

К. Ю. Манойлов, А. Ю. Лабинщев,
Н. В. Короткевич, Д. В. Колибо

Інститут біохімії ім. О. В. Палладіна

НАН України, Київ;

e-mail: manoilovmail@gmail.com

Субодиниця В дифтерійного токсину (ДТ) та iii R-домен відрізняються наявністю або відсутністю Т-домена. Метою роботи було проаналізувати взаємодію цих фрагментів токсину з клітинами ссавців для виявлення впливу Т-домену на ендоцитоз у резистентних клітинах. Інтерналізація рекомбінантних флуоресцентних похідних субодиниці B та R-домену була охарактеризована в резистентних клітинах L929, що походять із сполучної тканини миші, та токсинчутливих клітинах Vero з нирок африканської зеленої мавпи. Встановлено, що в процесі інкубації клітин за одночасної присутності субодиниці B та R-домену в культуральному середовищі, клітини Vero інтерналізували більше молекул субодиниці B, ніж R-домену. За таких самих умов клітини L929 інтерналізували більше молекул R-домену, ніж субодиниці B. Колокалізація флуоресцентних субодиниці В та R-домену в клітинах L929 була швидкою та відбувалась практично повністю на ранніх стадіях інкубації порівняно з клітинами Vero, в яких вона була повільна і відбувалась поступово. Одержані дані вказують на те, що Т-домен впливає на інтерналізацію та ендосомальний транспорт ДТ в клітинах відповідно до їхньої чутливості до токсину. Дійшли висновку, що лише в токсинчутливих клітинах Т-домен бере участь у внутрішньоклітинному ендосомальному транспорті та сортуванні ДТ шляхом підсилення інтерналізації молекул токсину.

К л ю чо в і с лов а: дифтерійний токсин, інтерналізація, proHB-EGF, конфокальна мікроскопія.

\section{УСИЛЕНИЕ ИНТЕРНАЛИЗАЦИИ \\ РЕКОМБИНАНТНЫХ \\ ФРАГМЕНТОВ ДИФТЕРИЙНОГО \\ ТОКСИНА В ЧУВСТВИТЕЛЬНЫХ \\ КЛЕТКАХ, ОПОСРЕДОВАННОЕ Т-ДОМЕНОМ ТОКСИНА}

\author{
К. Ю. Манойлов, А. Ю. Лабыниев, \\ Н. В. Короткевич, Д. В. Колибо
}

\author{
Институт биохимии им. А. В. Палладина \\ НАН Украины, Киев; \\ e-mail: manoilovmail@gmail.com
}

Субъединица В дифтерийного токсина (ДТ) и её R-домен отличаются наличием или отсутствием Т-домена. Целью данной работы было проанализировать взаимодействие этих фрагментов токсина с клетками млекопитающих для выявления влияния Т-домена на эндоцитоз в резистентных клетках. Интернализация рекомбинантных флуоресцентных производных субъединицы B и R-домена была охарактеризована в резистентных клетках L929, происходящих из соединительной ткани мыши, и токсинчувствительных клетках Vero из почек африканской зеленой мартышки. Установлено, что в процессе инкубации клеток при одновременном присутствии субъединицы B и R-домена в культуральной среде, клетки Vero интернализовали больше молекул субъединицы B, чем R-домена. При тех же самых условиях клетки L929 интернализовали больше молекул R-домена, чем субъединицы B. Колокализация флуоресцентных субъединицы B и R-домена в клетках L929 была быстрой и происходила практически полностью на ранних стадиях инкубации по сравнению с клетками Vero, в которых она была медленная и происходила постепенно. Полученные данные указывают на то, что Т-домен влияет на интернализацию и эндосомальный транспорт ДТ в клетках в соответствии с их чувствительностью к токсину. Сделан вывод, что только в токсинчувствительных клетках Т-домен участвует во внутриклеточном эндосомальном транспорте и сортировке ДТ путем усиления интернализации молекул токсина.

К л ю че в ы е с лов в: дифтерийный токсин, интернализация, proHB-EGF, конфокальная микроскопия. 


\section{References}

1. Ladant D, Alouf JE, Popoff MR. The comprehensive sourcebook of bacterial protein toxins / Elsevier. 3rd ed. 2006, 1047 p.

2. Simpson JC, Smith DC, Roberts LM, Lord JM. Expression of mutant dynamin protects cells against diphtheria toxin but not against ricin. Exp Cell Res. 1998; 239(2): 293-300.

3. Abraham JA, Damm D, Bajardi A, Miller J, Klagsbrun M, Ezekowitz RA. Heparin-binding EGF-like growth factor: characterization of rat and mouse cDNA clones, protein domain conservation across species, and transcript expression in tissues. Biochem Biophys Res Commun. 1993; 190(1): 125-133.

4. Labyntsev AJ, Korotkevich NV, Kaberniuk AA, Romaniuk SI, Kolibo DV, Komisarenko SV. Interaction of diphtheria toxin B subunit with sensitive and insensitive mammalian cells. Ukr Biokhim Zhurn. 2010; 82(6): 65-75. (In Ukrainian).

5. Labyntsev AJ, Kolybo DV, Yurchenko ES, Kaberniuk AA, Korotkevych NV, Komisarenko SV. Effect of the T-domain on intracellular transport of diphtheria toxin. $U k r$ Biochem J. 2014; 86(3): 77-87.

6. Labyntsev AJ, Korotkevych NV, Kolybo DV, Komisarenko SV. Effect of diphtheria toxin T-domain on endosomal $\mathrm{pH}$. Ukr Biochem J. 2015; 87(4): 13-23.

7. Heagy WE, Neville DM Jr. Kinetics of protein synthesis inactivation by diphtheria toxin in toxin-resistant L cells. Evidence for a low efficiency receptor-mediated transport system. J Biol Chem. 1981; 256(24): 12788-12792.

8. Labyntsev AI, Korotkevich NV, Manoilov KI, Kaberniuk AA, Kolibo DV, Komisarenko SV. Recombinant fluorescent models for studying of diphtheria toxin. Bioorg Khim. 2014; 40(4): 433442. (In Russian).

9. Kaberniuk AA, Labyntsev AI, Kolybo DV, Oliynyk OS, Redchuk TA, Korotkevych NV, Horchev VF, Karakhim SO, Komisarenko SV. Fluorescent derivatives of diphtheria toxin subunit B and their interaction with Vero cells. Ukr Biokhim Zhurn. 2009; 81(1): 67-77. (In Ukrainian).

10. Manoilov KYu, Gorbatiuk OB, Usenko MO, Shatursky OYa, Borisova TA, Kolibo DV, Komisarenko SV. The characterization of purified recombinant fragment $\mathrm{B}$ as a tool to study diphtheria toxin. Dopov Nac Akad Nauk Ukr. 2017; (2): 88-99. (In Ukrainian).

11. Manoilov KYu, Gorbatiuk OB, Usenko MO, Shatursky OYa, Borisova TA, Kolibo DV. The characterization of purifed recombinant protein CRM197 as a tool to study diphtheria toxin. Dopov Nac acad nauk Ukr. 2016; (9): 124-133. (In Ukrainian).

12. Sanford KK, Earle WR, Likely GD. The growth in vitro of single isolated tissue cells. $J$ Natl Cancer Inst. 1948; 9(3): 229-246.

13. Mitamura $\mathrm{T}$, Higashiyama $\mathrm{S}$, Taniguchi $\mathrm{N}$, Klagsbrun M, Mekada E. Diphtheria toxin binds to the epidermal growth factor (EGF)like domain of human heparin-binding EGFlike growth factor/diphtheria toxin receptor and inhibits specifically its mitogenic activity. J Biol Chem. 1995; 270(3): 1015-1019.

14. Mitamura T, Umata T, Nakano F, Shishido Y, Toyoda T, Itai A, Kimura H, Mekada E. Structure-function analysis of the diphtheria toxin receptor toxin binding site by site-directed mutagenesis. J Biol Chem. 1997; 272(43): 2708427090.

15. Naglich JG, Metherall JE, Russell DW, Eidels L. Expression cloning of a diphtheria toxin receptor: identity with a heparin-binding EGFlike growth factor precursor. Cell. 1992; 69(6): 1051-1061.

16. Moehring JM, Moehring TJ. Comparison of diphtheria intoxication in human and nonhuman cell lines and their resistant variants. Infect Immun. 1976; 13(1): 221-228.

17. Moehring TJ, Moehring JM. Interaction of diphtheria toxin and its active subunit, fragment A, with toxin-sensitive and toxin-resistant cells. Infect Immun. 1976; 13(5): 1426-1432.

18. Piersma SJ, van der Gun JW, Hendriksen CF, Thalen M. Decreased sensitivity to diphtheria toxin of Vero cells cultured in serum-free medium. Biologicals. 2005; 33(2): 117-122.

19. Gabliks J, Falconer M. Interaction of diphtheria toxin with cell cultures from susceptibile and resistant animals. J Exp Med. 1966; 123(4): 723732.

20. Gibson AE, Noel RJ, Herlihy JT, Ward WF. Phenylarsine oxide inhibition of endocytosis: effects on asialofetuin internalization. Am J Physiol. 1989; 257(2 Pt 1): C182-C184. 
21. Schindelin J, Arganda-Carreras I, Frise E, Kaynig V, Longair M, Pietzsch T, Preibisch S, Rueden C, Saalfeld S, Schmid B, Tinevez JY, White DJ, Hartenstein V, Eliceiri K, Tomancak P, Cardona A. Fiji: an open-source platform for biological-image analysis. Nat Methods. 2012; 9(7): 676-682.

22. Dunn KW, Kamocka MM, McDonald JH. A practical guide to evaluating colocalization in biological microscopy. Am J Physiol Cell Physiol. 2011; 300(4): C723-C742.

23. Costes SV, Daelemans D, Cho EH, Dobbin Z, Pavlakis G, Lockett S. Automatic and quantitative measurement of protein-protein colocalization in live cells. Biophys J. 2004; 86(6): 3993-4003.

24. Murphy JR. Mechanism of diphtheria toxin catalytic domain delivery to the eukaryotic cell cytosol and the cellular factors that directly participate in the process. Toxins (Basel). 2011; 3(3): 294-308.

25. Trujillo C, Taylor-Parker J, Harrison R, Murphy JR. Essential lysine residues within transmembrane helix 1 of diphtheria toxin facilitate COPI binding and catalytic domain entry. Mol Microbiol. 2010; 76(4): 1010-1019.

Received 06.06.2017 